\title{
Variation of Entrances, Food Storage and Brood Cells of Trigona laeviceps Bees from Various Habitat
}

\author{
I Made Gatot Wija Damara*, Ni Luh Watiniasih, Ni Made Suartini \\ Program Study of Biology, Faculty of Mathematic \& Natural Sciences, Udayana University. Bukit Jimbaran, Bali. \\ *Corresponding author: gatotwijad@gmail.com
}

\begin{abstract}
Trigona is a stingless bee that protects itself by swarming and biting. The bee products that are widely used in addition to honey are propolis, wax and the royal jelly. Trigona bee is one of potentially honey producer that has not been widely known. One species of trigona bee found in Bali is the Trigona laeviceps. They are nested in the crevices of rocks or in the tree trunk. This research aims to determine variations of entrance shapes, food storage, and brood cells of T. laeviceps from different altitudes. Colonies were observed in the Laboratory of Animal Taxonomy, Biology Department, Faculty of Mathematics and Basic Sciences, Udayana University, and nest entrance was analyzed in the Analytic Laboratory, Udayana University. Colonies were collected from bamboo nest in a tubular form and wooden nest from wooden boxes. Nest entrance is either flat or protruded out of the nest in an oval shape. The form of the entrance is not affected by the altitude. The nest entrance contained around $0,05 \%$ flavonoids. The size and shape of pollen and honey pots volume was lightly lager in colonies collected from altitudes more than $400 \mathrm{~m}$ above sea level $\left(0.058 \pm 0.04 \mathrm{~mm}^{3}\right)$ than colonies collected from altitudes less than $400 \mathrm{~m}$ above sea level $\left(0.035 \pm 0.03 \mathrm{~mm}^{3}\right)$. Royal jelly pots and brood cells have also similar shapes, but the volume is larger in colonies collected from altitudes less than $400 \mathrm{~m}$ above sea level $\left(0.015 \pm 0.07 \mathrm{~mm}^{3}\right)$ compared to altitude of more than $400 \mathrm{~m}$ above sea level $\left(0.011 \pm 0.02 \mathrm{~mm}^{3}\right)$
\end{abstract}

Keywords: Trigona bees, Trigona laeviceps, nests entrance, pollen, honey.

\section{INTRODUCTION}

The Trigona bee is one of the stingless bees, that has a form of self-defense by biting its incoming predators. Trigona laeviceps have small body size $( \pm 4 \mathrm{~mm})$ compared with other honey-producing bees [1]. One of the Trigona bee species found in Bali is the T. laeviceps. The Genus of Trigona in Bali has been known widely distributed from a height of 5 metres above sea level up to 800 metres above sea level [2].

The trigona bee will generally make its nest in places that already has a gap or a small hole, such as on tree trunks, ground, and or on the wall. The trigona nests generally has an entrances with different shapes which is specific to species. The nest entrances are made of resins, propolis and a water-like saliva, mixed with soil to enhance the strength of the entrance $[3,4]$.

The inside of the trigona nest contains brood cells, honey pots, the pots of royal jelly batumen, that is a structure to support the cells and pots [5]. The trigona bees are highly social insects that lives in a colony, each bee has its own duty, the female queen is in charge of laying eggs, female working bees are responsible for cleaning the nest, feeding the broods, and searching for food, while the male bees are responsible for fertilizing the queen and keeping the nest from predators [6].

This study was conducted to identify the shape, size and materials used by the T. laeviceps to build the nest entrances of T. laeviceps as well as the size of the honey pots, pollen pots, brood cells, and royal jelly pots from colonies at different altitudes.

\section{RESEARCH METHODS}

Colony of Trigona laeviceps were collected from several habitats at different altitudes. Three colonies were collected from the altitude of $<400 \mathrm{~m}$ above sea level and another 3 colonies were from the altitude of $>400 \mathrm{~m}$ above sea level. Types of plants growing around the nests were recorded, as well as the temperature and humidity. Observation of the nest entrances i.e. length, width, and diameter of the entrances was conducted in situ with calipers.

The Ilustration of length and width measurement can be seen in Figure 1. Colonies were transported to the Laboratory of Animal Taxonomy, Department of Biology, Faculty of Mathematics and Basic Sciences, Udayana University, Bali for further examination. The honey and pollen pots, and the brood cells were harvested in the Lab, and measure with a caliper.

The flavonoids content of the nest entrance was analyzed in Spectrophotometric method using Quercetin as a standard following Rahman [7], conducted at the Laboratory of Food Technology Faculty of Udayana University. The diameter of nets entrance was measured using the following formula:

$$
\mathrm{d}=\mathbf{2} \times \mathbf{r}
$$

The diameter of the oval nest entrance:

Where :

d : Diameter

$r$ : radius 


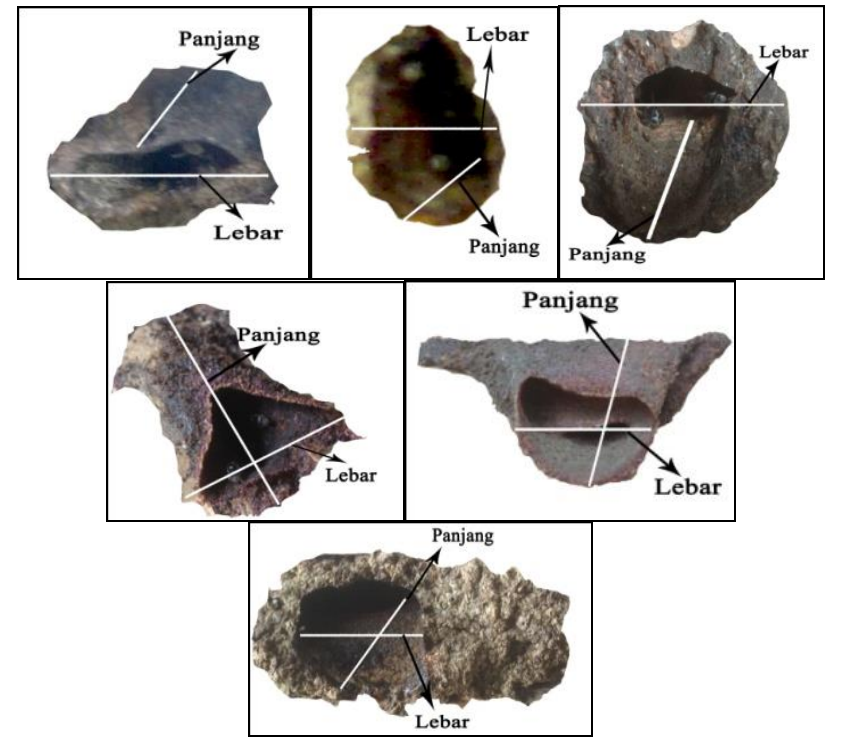

Fig. 1. Method of measuring the nest entrance of $T$. laeviceps in various shape of nest entrances.

The diameter of the oval nest entrance: $\mathrm{d}=\mathrm{a} \times \mathrm{b} \times \pi$ Where : $\mathrm{d}$ : Diameter

$$
\begin{aligned}
& a: \text { radius } a \\
& b: \operatorname{radius} b \\
& \pi: 3,14
\end{aligned}
$$

The volume of pollen and honey pots was measured by subsampling about $50 \%$ of the pots contained in the nest, while the volumw of royal jelly pots and the brood cells were measured from $25 \%$ of the cells contained in the nest following the formula:

Where: V: volume

$$
\mathrm{V}=3 / 4 \times \pi \times \mathrm{r}^{3}
$$

$$
\begin{aligned}
& \pi: 3,14 \\
& r: \text { radius }
\end{aligned}
$$

\section{RESULTS AND DISCUSSION}

Trigona laeviceps was found nested at a wide range of altitude, from around $5 \mathrm{~m}$ above sea level (asl) up to 759 $\mathrm{m}$ asl. It has been found by Michener [8] that Trigona was found at different altitude up to $800 \mathrm{~m}$ asl. At this study, samples were collected from different places with its specific environment, those were Serangan, Padangsambian, Gegelang, Pangsan, Mawang, and Duda. Serangan village is located at altitude of $5 \mathrm{~m}$ above sea level (asl) with an average temperature of $33^{\circ} \mathrm{C}$ and a $65 \%$ humidity. The village of Padangsambian is located at an altitude of $35 \mathrm{~m}$ asl, with the average temperature of $29^{\circ} \mathrm{C}$ and a $68 \%$ humidity.

The bee colonies at these two villages were found in the settlement area. The village of Gegelang lies at an altitude of $189 \mathrm{~m}$ asl, with the average temperature of $29.3^{\circ} \mathrm{C}$ and a $66 \%$ humidity, while the bee colony are found at the plantation area. Pangsan Village is located at high altitude ( $487 \mathrm{~m}$ asl) with an average temperature of $26.6^{\circ} \mathrm{C}$ and a $68 \%$ humidity. Bee colonies were found at the settlements and around salak (Salaca edulis) plantations. Mawang Village is located at altitude of $759 \mathrm{~m}$ asl, with an average temperature of $27.9^{\circ} \mathrm{C}$ and a $76 \%$ humidity where bee colonies found at the cacao plantation area. Duda Village is located at an altitude of $503 \mathrm{~m}$ asl with an average temperature of $26^{\circ} \mathrm{C}$ and a $67 \%$ humidity, and bee colony was found around salak plantation.

Colonies of the Trigona bee were found nested in bamboo and in a wooden boxes (Figure 2). In the other site word wide, Trigona bee were found nested in the plant holes, wall and in other crevices [9]. Sakagami et.al [3] found that $T$. laeviceps was nesting in the cracks of buildings and soil.

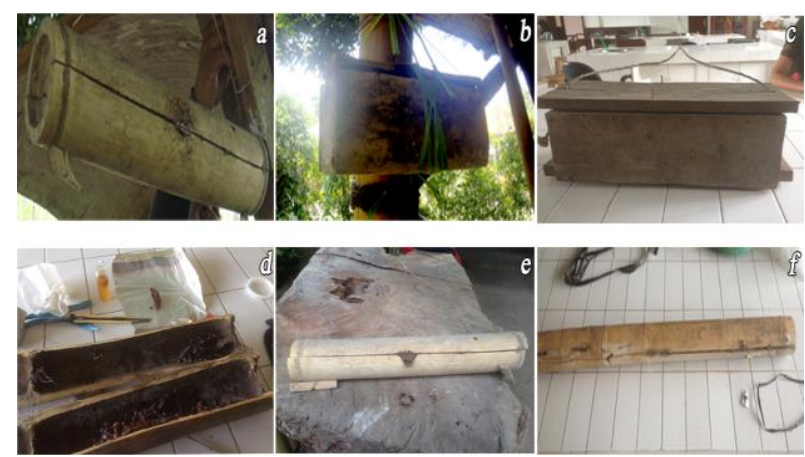

Fig. 2. Shape of the T. laeviceps nest: in bamboo (a,d,e,f) and in wooden box $(\mathrm{b}, \mathrm{c})$.

The entrance of the nests of $T$. laeviceps was found located at the side or near the bottom part of the nests in protrude oval shape, with diameter range from 0.09 to 1.68 $\mathrm{mm}$. The variation of nest entrance found in this study is presented in Figure 3.

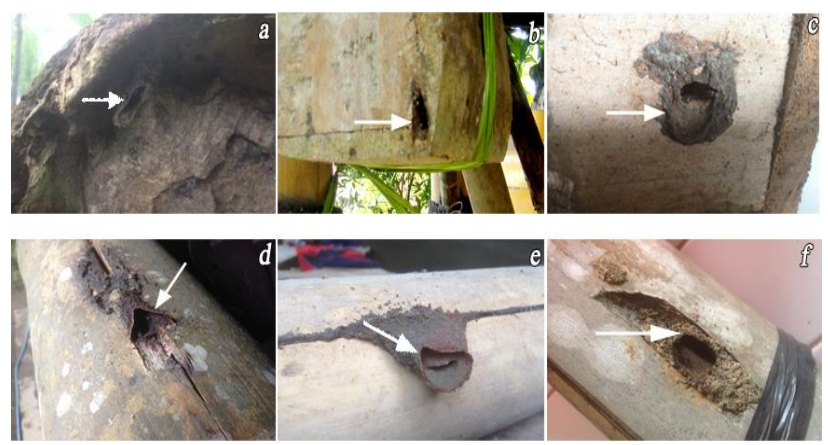

Fig. 3. Variations form of the T. laeviceps nest entrance collected from different location: (a) Serangan, (b) Padangsambian, (c) Gegelang, (d) Pangsan, (e) Mawang, and (f) Duda villages.

The size of the nest entrance was slightly larger (average $2.96 \mathrm{~mm}$ ) in colonies collected from altitude of $>400 \mathrm{~m}$ asl compared to habitats with altitudes of $<400 \mathrm{~m}$ asl (average $1.97 \mathrm{~mm}$ ). The analysis of material that used to build the nest entrance was found contain of flavonoids in varying concentrations. Flavonoids are synthesized by plants as a small molecule of secondary metabolites with various biological activities [10]. In general, the flavonoid content of the nest entrance of trigona nest was less than $0.05 \%$ (Table 1). The entrance of a tube-shaped nest will 
directly leads the foraging individuals into the nest and to the food storage [11]. The entrance for trigona bees also serves as a nest defense against predatory attacks [3]. The variation of flavonoid content of the nest entrance may depend on the time and plant visited while the forager bees foraging for flavonoids. The present and the biological function of the flavonoids in plants were found as defens eagainst UV-B radiation and pathogen infection [12].

TABLE 1.

FLAVONOID CONTENT OF T. LAEVICEPS NEST ENTRANCE COLLECTED FROM DIFFERENT HABITATS OF DIFFERENT ALTITUDES.

\begin{tabular}{ccc}
\hline $\begin{array}{c}\text { Altitude } \\
(\mathrm{m} \text { asl })\end{array}$ & Sampling site & $\begin{array}{c}\text { Flavonoid content } \\
(\%)\end{array}$ \\
\hline$<400$ & Serangan & 0,044 \\
$<400$ & Padangsambian & 0,017 \\
$<400$ & Gegelang & 0,104 \\
$>400$ & Pangsan & 0,021 \\
$>400$ & Mawang & 0,026 \\
$>400$ & Duda & 0,031 \\
\hline
\end{tabular}

The length of pollen and honey pots did not differ in habitats with altitudes $<400 \mathrm{~m}$ asl $(0.98 \pm 0.02 \mathrm{~mm})$, but in the habitats with the altitudes $>400 \mathrm{~m}$ asl, the pollen pot is slightly shorter $(1.00 \pm 0.03 \mathrm{~mm})$ than the honey pot $(1.05$ $\pm 0.03 \mathrm{~mm})$. The width of the pollen pots were similar at different altitudes, in average of $0.75 \pm 0.02 \mathrm{~mm}$, while the width of the honey range from $0.74 \pm 0.02 \mathrm{~mm}$ at the altitude of $>400 \mathrm{~m}$ asl, slightly shorter than that of $<400 \mathrm{~m}$ asl (0.78 $\pm 0.02 \mathrm{~mm})$. (Figure 4). .

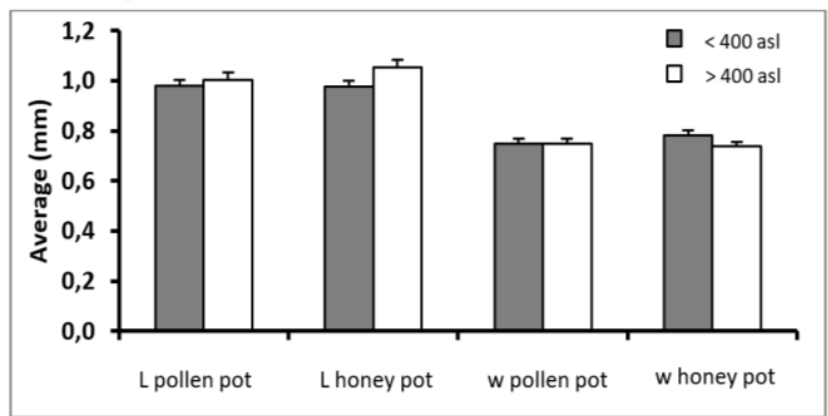

Fig. 4. Average length and width of pollen and honey pots of $T$. laeviceps collected from 2 different altitude $<400 \mathrm{~m}$ asland $>400 \mathrm{~m}$ asl. $1=$ length, $\mathrm{w}=$ width.

The length of brood cells and royal jelly pots differed in both habitats. In habitats with altitudes of $<400 \mathrm{~m}$ above sea level, the royal jelly pots were slightly longer with a mean of $(0.47 \pm 0.03 \mathrm{~mm})$, compared to habitats with altitudes $>400 \mathrm{~m}$ above sea level. The average length of the brood cells and the royal jelly pot was $0.45 \pm 0.02 \mathrm{~mm}$. The width of brood cell and the royal jelly pots in the habitat with altitude $<400 \mathrm{~m}$ asl was found wider $(0.35 \pm$ $0.02 \mathrm{~mm})$ compared to habitat with the altitude of $>400 \mathrm{~m}$ asl $(0.33 \pm 0.02 \mathrm{~mm})$, with the detail is presented in Figure 5 .

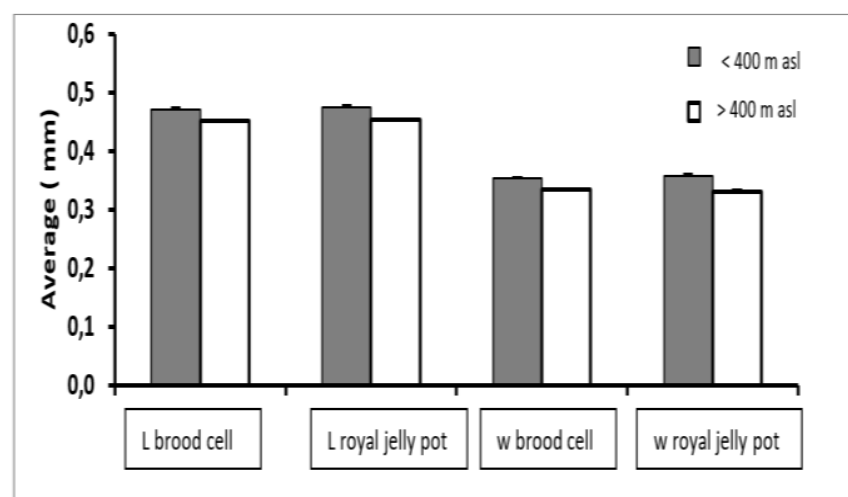

Fig, 5. Average length and width of brood cells and royal jelly pot, of $T$. laeviceps in habitats with different altitude. $1=$ length, $\mathrm{w}=$ width

The average volume of brood cells and royal jelly pots of T. laeviceps was slightly larger at $<400 \mathrm{~m}$ altitude. But the volume of honey pots and pollen pots was slightly lower in habitats with altitudes $<400 \mathrm{~m}$ above sea level compared with the same variables in the habitat with altitude $>400 \mathrm{~m}$ above sea level. For example, the volume of brood cells in colonies from habitats with altitudes $<400$ $\mathrm{m}$ is $0.12 \mathrm{~mm}^{3}$ which is slightly higher than the volume of brood cells in colonies from habitats with altitudes $>400 \mathrm{~m}$ above sea level $(0.010 \mathrm{~mm} 3)$, as well as the volume of royal jelly pots with a volume of $0.16 \mathrm{~mm}^{3}$ in colonies from habitats with altitudes $<400 \mathrm{~m}$ above sea level compared to colonies of habitats $>400 \mathrm{~m}$ above sea level which has a volume of $0.11 \mathrm{~mm}^{3}$.

However, the average volume of pollen pots is higher in colonies collected from habitats with altitudes $>400 \mathrm{~m}$ above sea level. (0.59 mm3) compared with colonies of habitats with altitudes $<400 \mathrm{~m}$ above sea level. $(0.35 \mathrm{~mm} 3)$ (Figure 6). Hamzah et al. [13] states that bees will be faster at producing food reserves and certainly higher food reserves at higher altitudes compared with lower altitudes. The range of temperature that suitable for bees to grow and foraging is between $16-26^{\circ} \mathrm{C}$ [14].

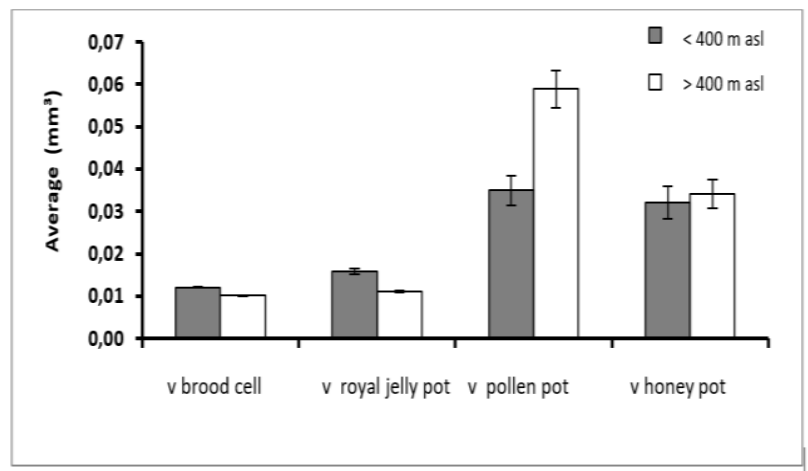

Fig. 6. Average volume of brood cells, royal jelly, pollen and honey pots of T. laeviceps from habitats with different altitudes. $\mathrm{v}=$ volume.

Plants that were found growing around the nest at the altitudes of $<400 \mathrm{~m}$ asl mostly bush and herb type of plants such as Impatiens balsamina L, Euphorbia sp., and 
Bougainville sp., while plants that were found growing in the habitat with the altitude of $>400$ m mostly in tree types, such as Theobroma cacao and Manilkara zapota serounded by grasses. According to Orwa [15], The flavonoid content in the sapodilla tree (Manilkara zapota) and mango (Mangifera sp.) was found in the stems, leaves and in bark [16].

\section{CONCLUSION}

Trigona laeviceps in Bali was found nested at a wide range of altitude up to $800 \mathrm{~m}$ above sea level in bambbo and wooden boxes. The nest entrance was oval shaped and contain of concentration of flavonoids depend on the habitat of the colonies. The length of pollen and honey pots was similar between altitudes, but the width of honey pots was slightly shorter at lower altitude. The length of brood cell and the royal jelly pots was slightly longer and wider at lower altitude. The volume of pollen and honey pots were larger in colonies collected from altitude of > $400 \mathrm{~m}$ asl compared to colonies collected from altitude of $<400 \mathrm{~m}$ above sea level. Volume of royal jelly pots was greater in colonies collected from altitude of $<400 \mathrm{~m}$ asl compared to altitude of $>400 \mathrm{~m}$ above sea level.

\section{ACKNOWLEDGMENT}

This research was proudly funded by The Ministry of Research and Technology, Republic of Indonesian, under Research Grant No. 486.10/UN14.2/PNL.01.03.00/2016

\section{REFERENCES}

[1] Nunes S. P, S. D. Hilario, P. S. S. Filho, and V. L. I. Fonseca VLI (2010) Foraging Activity in Plebeia remota, a Stingless Bees Species, is Influenced by the Reproductive State of a Colony. Psyche 2010: Article ID 241204, 16p.

[2] Watiniasih, N. L., dan N. M. Suartini. 2014. Keragaman Lebah Trigona sebagai Salah Satu Plasma Nutfah di Bali Selatan. Prosiding Seminar Sains danTeknologiTahun 2014.Lembaga Penelitian dan Pengabdian Kepada Masyarakat, Universitas Udayana, 18 - 19 September 2014, Denpasar, Bali.

[3] Sakagami, S. F., T. Inoue, S. Yamane, and S, Salmah. 1983. Nest Architecture and Colony Composition of The Sumatran Stingless Bee Trigona (Tetragonula) laeviceps. Kontyu.51:100-111.
[4] Rasmussen, C. and Camarago. 2008. Molecular Phylogeny of Stingless Bees: Insights into Divergence Times, Biogeography, and Nest Architecture Evolution (Hymenoptera: Apidae: Meliponini). Ph.DDissertation, University of Illinois at Urbana-Champaign, USA, iii + $301 \mathrm{pp}$.

[5] Franck, P., E. Cameron., G. Good., Y. Rasplus and B. P. ldroyd. 2004. Nest Architecture and Genetic Differentiation in a Species Complex of Australian Stingless Bees. Molecular Ecology. 13: 2317-2331.

[6] Michener, C. D. 1974. The Social Behaviour of The Bees. Cambridge: The Belknap of Harvard Univ Press, Cambridge: xii \pm 312 pp.

[7] Rahman, A. dan Utari. 2006. Aktivitas Antioksidan Kandungan Fenolat Total dan Kandungan Flavonoid Total Ekstraksi Etil Asetat Buah Mengkudu serta Reaksi-reaksinya., Majalah Farmasi Indonesia (17:137-13).

[8] Michener, C.D. 2007. The Bees of The World. The John Hopkins University Press: London.

[9] Dollin, A. E., L. J. Dollin. and S. F. Sakagami. 1997. Australian stingles bees of the genus Trigona (Hymenoptera: Apidae). Invertebr. Taxon. 11: 861896.

[10] Mierziak J, K. Kostyn, and A. Kulma. 2014. Flavonoids as Important Molecules of Plant Interactions with the Environment. Molecules 19: 16240-16265; doi:10.3390/molecules 191016240

[11] Free, J. B. 1982. Bees and Mankind. George Allen \& Unwin, London: $\mathrm{xi}+455 \mathrm{pp}$

[12] Ferreyra, M. L. F., S. P. Rius and P. Casati. 2012. Flavonoids: biosynthesis, biological functions, and biotechnological applications. Frontiers in Plant Science 3: 1-15. doi: 10.3389/fpls.2012.00222.

[13] Hamzah, D., H. Elfawati., dan H. Jully, 2011.Produksi Lebah Madu (Apis cerana) yang Dipelihara padasarang Tradisional dan Modern di Desa Kuapan Kecamatan Tambang Kabupaten Kampar.

[14] Salmah, S. 1983 Aspek Morphologi dan Ekologi Lebah tak Bersengat Trigona (Tetragonula)laeviceps smith di Sumatera Barat in: Prosiding Kongress Entomologi II, Jakarta.

[15] Orwa. 2009. Caesalpiniasappan Linn. Agroforestry Database 4.0. http://www.worldagroforestry.org/ treedb2/AFTPDFS/Caesalpinia_sappan pdf.

[16] Siregar HCH. Fuah AM. Octavianty Y. 2011. Propolis Madu Multikhasiat. Penebar Swadaya.Jakarta. 